\title{
NEURAL NETWORKS - A WAY TO INCREASE THE FUEL EFFICIENCY OF VEHICLES
}

\author{
MILESICH Tomáśs ${ }^{1}$ DANKO Ján ${ }^{1}$, BUCHA Jozef ${ }^{1}$ \\ ${ }^{I}$ Slovak University of Technology in Bratislava, Faculty of Mechanical Engineering, Institute of Transport \\ Technology and Designing, Nám. slobody 17,812 31 Bratislava, Slovakia, email: tomas.milesich@stuba.sk
}

\begin{abstract}
This paper deals with the possibility of creating a vehicle model using a hierarchy of neural networks. Based on this model, it is possible to build an optimization cycle that looks for parameters which are influencing the driving of vehicles along given path. The given path must include a driving through the town, out of town and along the highway section, so the test track contains the greatest number of driving modes. Data for neural network are obtained from the CAN bus and the GPS sensor. Based on the built model and given route it is looking for such route drive, where it eventually came that the development of fuel consumption is lower than in unoptimized drive.
\end{abstract}

KEYWORDS: Eco-driving, Neural networks, CAN-bus, GeoTIFF.

\section{The effect of an eco-driving on vehicle fuel efficiency}

Article deals with the possibility of applying theoretical knowledge in the field of the application of neural networks to implement them in design of the virtual vehicle model. This is pointing out the possibility of making the operation of the vehicle more effective from the perspective of the operator of the vehicle. During vehicle operation, it is necessary to deal with increase of efficiency of the energy contained in the fuel required to drive vehicles for the transport of persons and goods. In the EU, the road transport has the highest percentage of transported goods (44.2\%) [1]. Claims for professional drivers in road haulage in terms of driving operation economy are high.

Nowadays drivers have in vehicles various assistance components, these components are able to evaluate the current condition of the vehicle and can determine the current optimal state, inform the driver how to operate the actuator such as an optimal gear. The response of the vehicle during driving on the track is dependent solely on the driver of the vehicle [2]. Such assistance systems, however cannot estimate the character of the route. This character can be represented with i.e. Speed profile of specific route.

A Dutch research team studied the effects of following Dutch eco-driving tips on fuel consumption and emissions in 2002. The study indicates that eco-driving techniques can reduce fuel consumption by $7 \%$ to $10 \%$, depending on vehicle type (diesel or petrol) [3]. Drivers of passenger cars as well as truck drivers have some bad habits showing when driving.

They are particularly:

- Late braking

- Incorrect shifting

- Failure to comply with the prescribed average driving speed for a given route 
These bad habits should be eliminated because they adversely affect the efficiency of operation of the vehicle in terms of fuel consumption and consequently kilometers shipping costs.

Economy of the vehicles is determined by the amount of fuel consumed in the driveline, which is equivalent to the energy consumption, because the energy required to move the vehicle is carried by fuel. Nowadays the main control element of the motor vehicle remains human, depends on how efficiently the driver can ride the vehicle. Therefore, professional drivers undergo various training courses about driving techniques.

Main rules of eco-driving by [4] are:

- Shift up as soon as possible

- Maintain a steady speed

- Anticipate traffic flow

- Decelerate smoothly

\section{Specifying of heavy duty vehicle driving test}

IVECO Stralis was selected as heavy duty test vehicle, engine used in vehicle is CURSOR10 six-cylinder supercharging diesel, with variable turbocharger geometry, four valves per cylinder, $\mathrm{OHC}$, having a engine displacement of $10,308 \mathrm{~cm}^{3}$, the maximum brake power is $338 \mathrm{~kW}$ by $1560-2100 \mathrm{RPM}$, maximum brake torque $2100 \mathrm{Nm}$ by $1050-1550$ RPM. Vehicle transmission is 12 gears, electronically synchronized automatic transmission for heavy trucks (ZF 12AS2330TD).

The European Commission in 2011 devoted to the study [5], where the average driving mode was defined for different vehicle categories based on data from individual rides. In the category of heavy duty vehicles, under defined conditions achieved by this study, vehicle achieved lowest specific consumption of $180 \mathrm{~g} / \mathrm{kWh}$ to $195 \mathrm{~g} / \mathrm{kWh}$, these are the vehicles of performance classes from $353 \mathrm{~kW}$ to $485 \mathrm{~kW}$. The study also found that vehicles of this performance class drive during single a driving mode from 120 to 160 kilometers at an average speed of $43-52 \mathrm{~km} / \mathrm{h}$. Driving mode is represented by driving through urban area, through rural area and along motorways.

- Urban area - vehicle speed under $50 \mathrm{~km} / \mathrm{h}$

- $21 \%$ from overall driving mode

- Rural area - vehicle speed from $50-70 \mathrm{~km} / \mathrm{h}$

- $15 \%$ from overall driving mode

- Motorway - vehicle speed over $70 \mathrm{~km} / \mathrm{h}$

$-63 \%$ from overall driving mode

\section{Track determination for drive test}

The test track should include motorway section part, urban section and rural section. These conditions were met by route from Bratislava, driving through Bratislava was urban section of path, the motorway section leading to Trnava and around it, rural section from Trnava went towards Jablonica on 1st class road. The highest ascent occurred between Trstín and Jablonica.

Fig. 1 shows the path in two types of view, the left view is based on GeoTIFF. TIFF 'Tagged Image File Format' image is a file format for storing raster computer graphics. This file can be used for storing information such as geo-referenced information as the coordinate system, the values of latitude and longitude and altitude, in this case, a file format is GeoTIFF, respectively DEM data. The Digital Elevation Model (DEM) over Europe from the GMES RDA project (EU-DEM) is a Digital Surface Model (DSM) representing the first 
surface as illuminated by the sensors. The EU-DEM dataset is a realization of the Copernicus programme, managed by the European Commission, DG Enterprise and Industry. This data was imported to the Matlab environment through TIFF data.
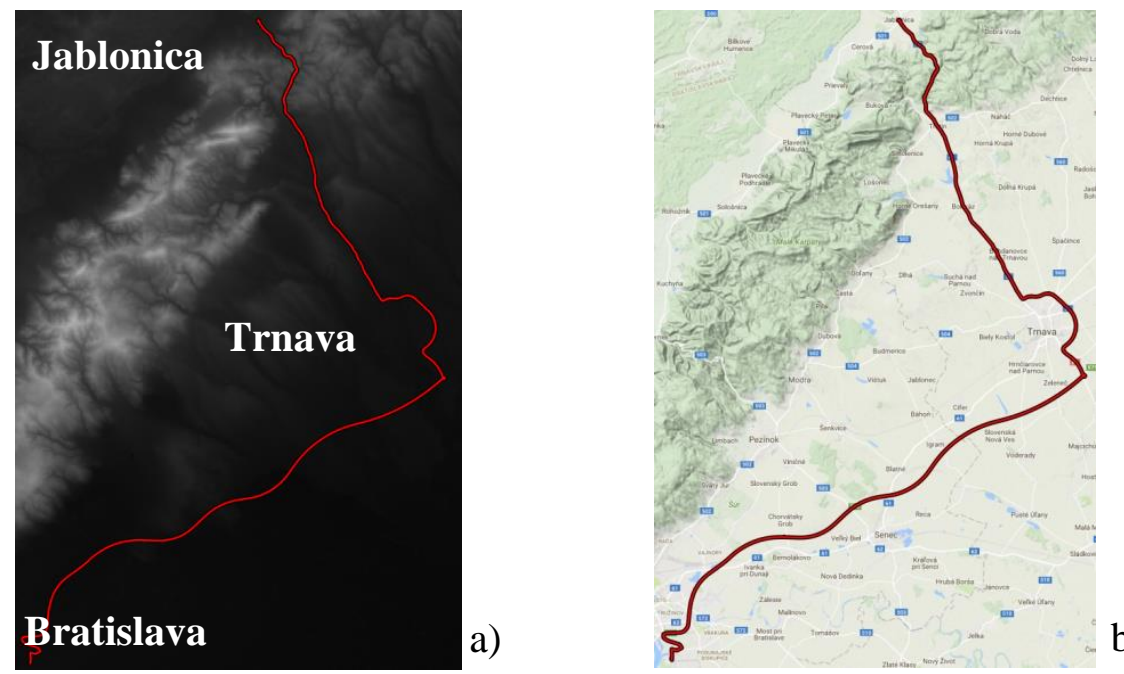

b)

Fig. 1 The route selected for driving test

a) GeoTIFF map b) Google Physical map

\section{Data acquisition from vehicle}

Getting data about the position of vehicles in the GPS coordinates was done by GPS locator u-blox NEO-6M. In case of real-time data processing is suitable converter VECTOR VN1610, which communicates with the software Matlab/Simulink. VN1610 converter is also fully compatible with CAN 2.0 A/B by Standard ISO 11898, speed of data reading is 2 Mbit/s. [7] Communication with CAN bus was ensured by a direct connection to the serial pair CAN_H and CAN_L.

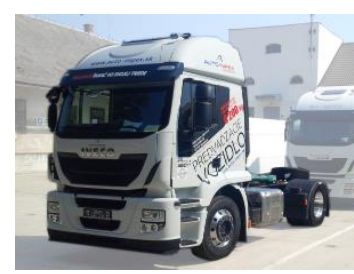

Vehicle

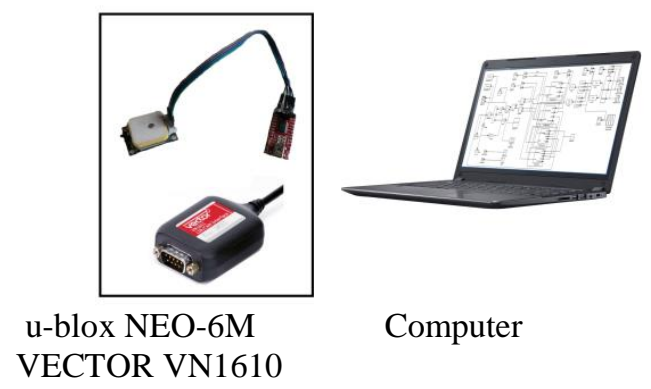

Fig. 2 Data collecting chain

From the vehicle to a computer data were scanned using data collecting chain, where the data were further processed. Based on the data from the CAN bus, a model of the vehicle, which describes the driving condition of a given path, could be designed. For heavy duty vehicle decoding messages from the CAN bus was based on FMS standard.

The data used to create the model were engine speed, actual gear ratio, travelled distance, vehicle speed, road grade profile, engine percent load, actual engine torque, the current consumption, GPS position. The values of the road grade were defined by the map based on GeoTIFF. 


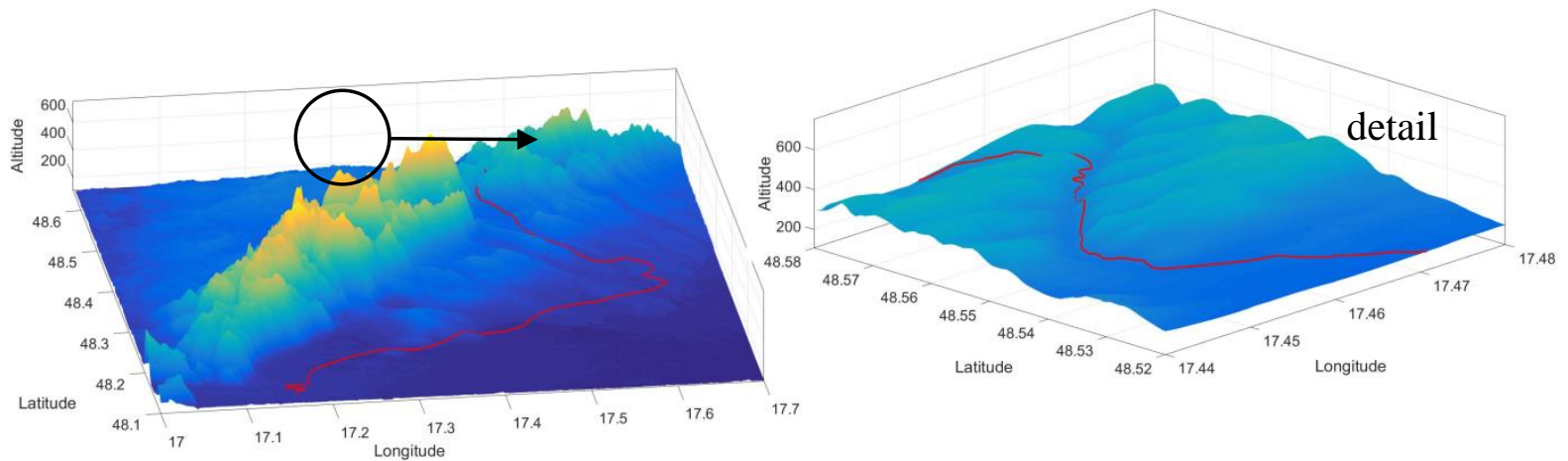

Fig. 3. Road grade data from GeoTIFF

The test path (Fig. 3) contained elevation $300 \mathrm{~m}$, the path measured $85 \mathrm{~km}$ and was traveled in both directions, which means that the total length of the path reached $170 \mathrm{~km}$. The average speed of ride was $71.1 \mathrm{~km} / \mathrm{h}$ towards the Jablonica, back, the average was $71.5 \mathrm{~km} / \mathrm{h}$. Speed characteristic in dependence on the traveled distance on the track towards the Jablonica is shown in Fig. 4, in the area marked as A, vehicle came to a halt and subsequently accelerating, the impact on current fuel consumption is shown in Fig. 5.

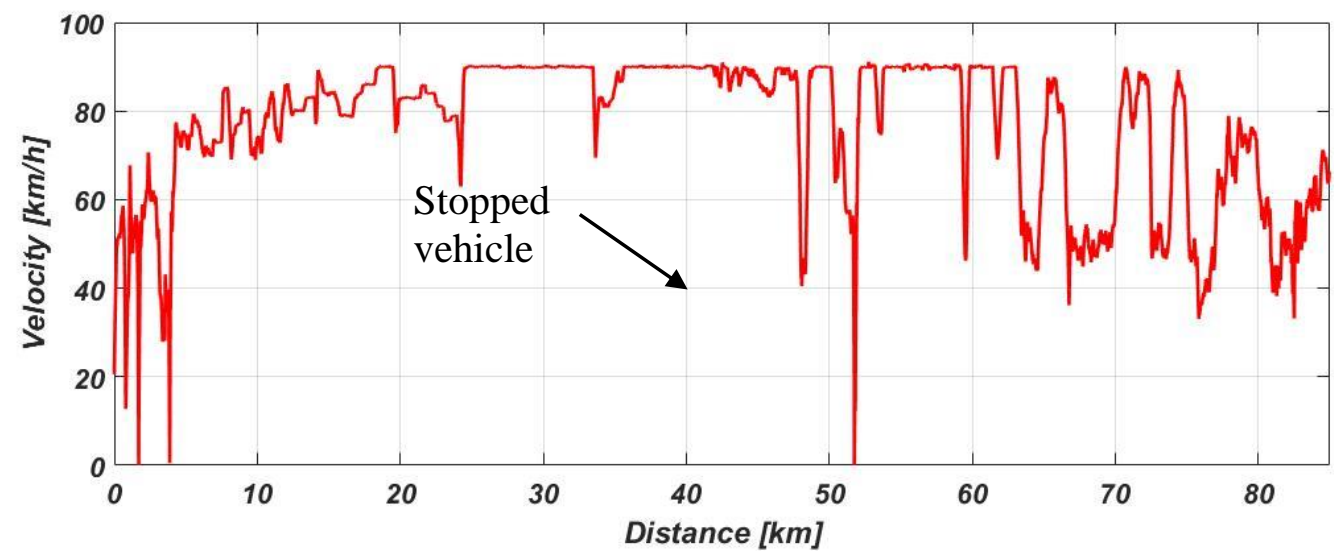

Fig. 4 Vehicle passing speed course

In this case, stopping of the vehicle is an error of driver, because it is necessary to put the vehicle in motion again. This situation has a negative impact on fuel consumption.
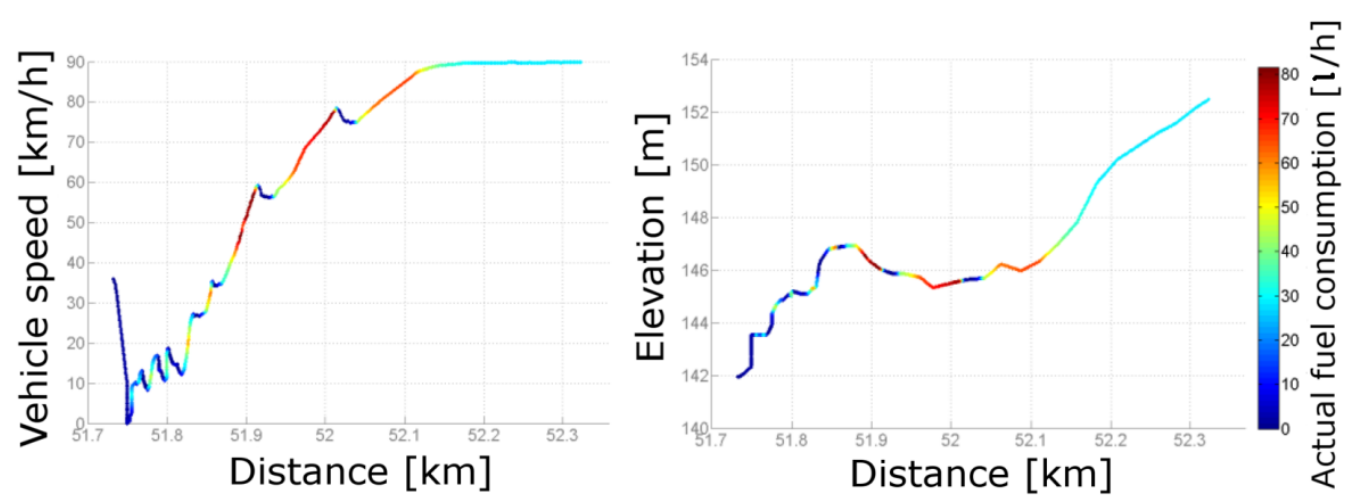

Fig. 5 The course of the vehicle speed and the altitude profile of the road, 
depending on the current fuel consumption

\section{The neural networks in vehicle model design}

The principle of neural networks has recently begun to use more and more often. Based on ability to provide learned outputs for inputs in real time at low computational load may be used to solve complex problems, where the mathematical description of the process is difficult to describe, or is a great need for computing resources. The mathematical model using large computation power is used in papers [7-9]. Creating a mathematical model of the vehicle using neural network represents a new approach to modeling of the vehicle. The philosophy of this paper is based on the data usage which provides a connection to the CAN bus. Vehicle model is based on a certain hierarchy of neural networks (Fig.6). The input parameters to the vehicle model representing the engine speed, used gear and the data of the actual elevation. Information about the current elevation is always obtained in two consecutive values of the current altitude. These parameters are input into the system by which the driver interacts with the driving process.

Table 1. Input and output data of neural network

\begin{tabular}{|c|c|c|}
\hline Title of NN & Input to the $\mathrm{NN}$ & Output from the NN \\
\hline $\mathrm{nm}-\mathrm{i} 2 \mathrm{v}$ & engine speed, actual gear ratio & vehicle speed \\
\hline$n m-i-v-t 2 d$ & $\begin{array}{l}\text { engine speed, actual gear ratio, vehicle } \\
\text { speed from nm-i } 2 v \text {, time }\end{array}$ & distance \\
\hline $\mathrm{d} 2 \mathrm{~s}$ & $\begin{array}{l}\text { distance from nm-i-v-t } 2 d \text {, data from } \\
\text { GPS by GeoTIFF data }\end{array}$ & road grade \\
\hline nm-i-v-s2epl & $\begin{array}{l}\text { engine speed, actual gear ratio, vehicle } \\
\text { speed from nm-i } 2 v \text {, distance from nm-i- } \\
\text { v-t } 2 d \text {, road grade from } d 2 s\end{array}$ & engine percent load \\
\hline nm-i-v-s-epl2aet & $\begin{array}{l}\text { engine speed, actual gear ratio, vehicle } \\
\text { speed from nm-i2v, distance from nm-i- } \\
\mathrm{v}-\mathrm{t} 2 \mathrm{~d} \text {, road grade from } \mathrm{d} 2 \mathrm{~s} \text {, engine } \\
\text { percent load from nm-i-v-s2epl }\end{array}$ & actual engine torque \\
\hline nm-i-v-s-epl-aet $2 \mathrm{fr}$ & $\begin{array}{l}\text { engine speed, actual gear ratio, vehicle } \\
\text { speed from nm-i } 2 \mathrm{v} \text {, distance from nm-i- } \\
\mathrm{v}-\mathrm{t} 2 \mathrm{~d} \text {, road grade from } \mathrm{d} 2 \mathrm{~s} \text {, engine } \\
\text { percent load from nm-i-v-s2epl, actual } \\
\text { engine torque from nm-i-v-s-epl2aet }\end{array}$ & fuel rate \\
\hline
\end{tabular}

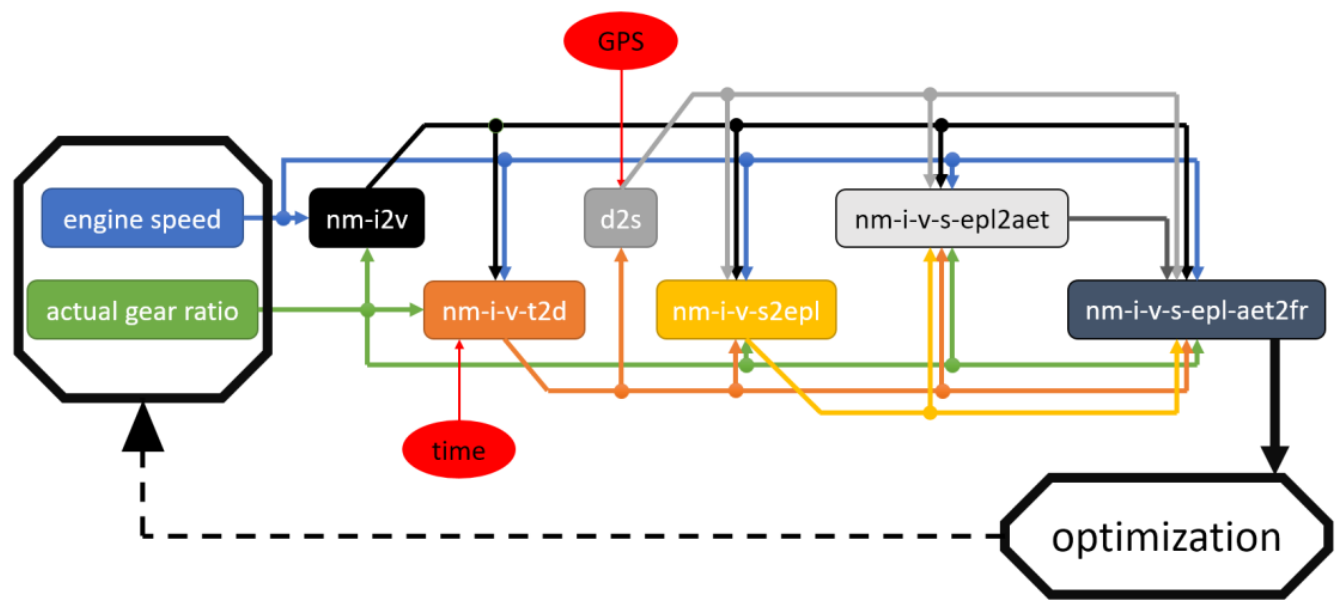

Fig. 6 Neural network hierarchy 
Optimization cycle was designed so that information on actual fuel consumption is recalculated on the development of average fuel consumption and searched parameters in the form of engine speed were sought by optimization method while the final value of the average fuel consumption is not less than the predetermined value. Optimization cycle has assessed that certain sections of the path were suitable to pass on higher engine speed, so then when driving at motorway section could vehicle pass at lower speeds, or at lower engine speeds, making it possible to reduce the average fuel consumption while maintaining travel time. When passing route, which measured $85 \mathrm{~km}$ theoretical reduction of the average fuel consumption was from $17.51 / 100 \mathrm{~km}$ to $15.41 / 100 \mathrm{~km}$, which represents a decrease of $12 \%$. Reduced average fuel consumption was reflected in the reduction of overall fuel consumption as shown in Fig. 8, which was reduced from 16.951 to 14.911.

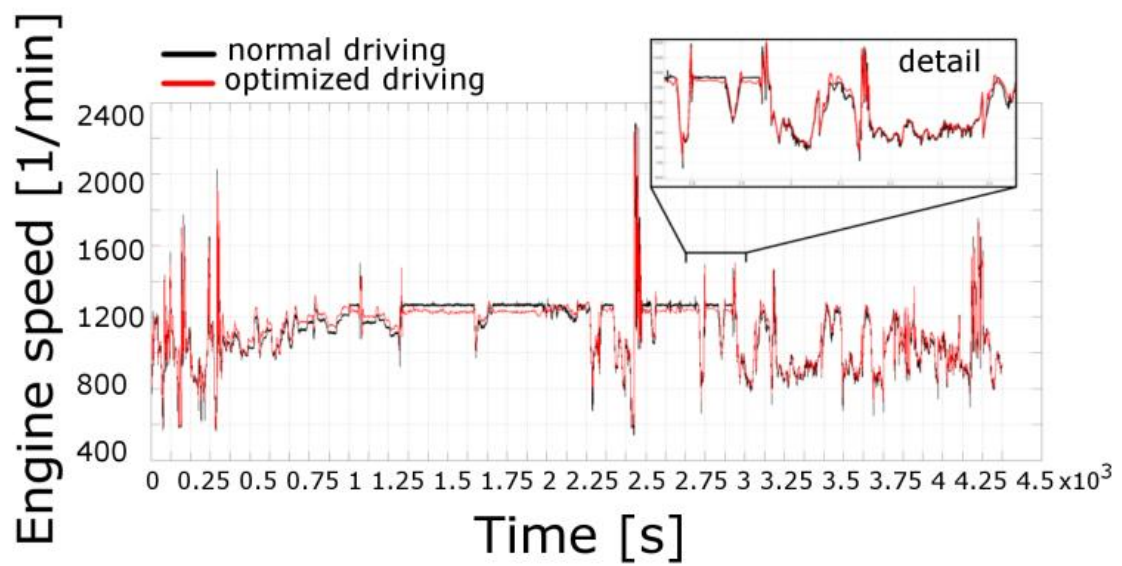

Fig. 7 The course of engine speed during driving

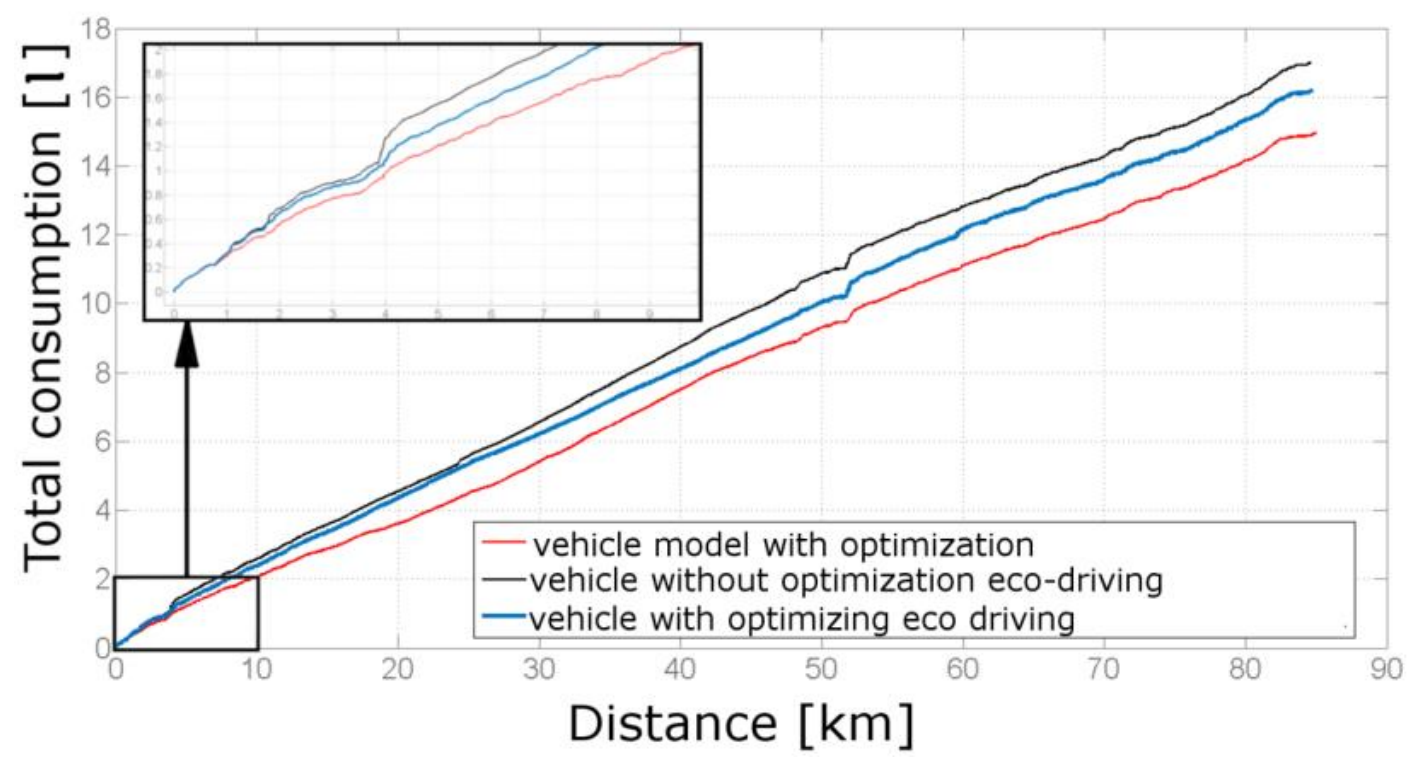

Fig. 8 The development of the overall fuel consumption 
Table 2 Evaluation of drive

\begin{tabular}{ccccc}
\hline Type of drive & $\begin{array}{c}\text { Distance } \\
{[\mathrm{km}]}\end{array}$ & Time & $\begin{array}{c}\text { Average } \\
\text { consumption } \\
{[\mathrm{L} / 100 \mathrm{~km}]}\end{array}$ & $\begin{array}{c}\text { Total } \\
\text { consumption } \\
{[\mathrm{L}]}\end{array}$ \\
\hline $\begin{array}{c}\text { Development of average } \\
\text { fuel consumption of the } \\
\text { vehicle model }\end{array}$ & 84.9 & $1: 11: 21$ & 20.69 & 14.96 \\
$\begin{array}{c}\text { Development of average } \\
\text { fuel consumption during test } \\
\text { drive }\end{array}$ & 84.9 & $1: 11: 32$ & 23.11 & 17.01 \\
$\begin{array}{c}\text { Development of average } \\
\text { fuel consumption } \\
\text { verification drive }\end{array}$ & 84.9 & $1: 13: 28$ & 21.99 & 16.21 \\
\hline
\end{tabular}

\section{CONCLUSIONS}

Average fuel consumption during the verification drive stabilized at $221 / 100 \mathrm{~km}$, which in consultation with professional drivers is considered as above average good fuel consumption. The resulting decline in average consumptions are reflected in the decrease of total consumption compared to the first drive. Decrease of 0.81 in $84.9 \mathrm{~km}$, which is $4.7 \%$ compared to the first drive in which data was collected to create the model. Evaluation of drives is shown in Table 2, each drive has the same path, because the vehicle always started from the same place and the end time of data recording was also approximately same. Passing time in the test drive is lower than driving of the vehicle model with optimized technique of ride. Condition in optimization cycle in Matlab/Simulink was length of traveled track.

\section{REFERENCES}

[1] Panorama of Transport. Eurostat. Belgium: Office for Official Publications of the European Communities. 2007.

[2] I. Drahotsky, J. Pokorný, P. Jilek. Odezva nákladního vozidla při přejezdu překážky. In ExFoS 2017: XXVI. mezinárodní vědecká konference soudního inženýrství: sborník př́spěvků. Brno: Vysoké učení technické v Brně, 2017, 89 - 104.

[3] R. J. Vermeulen. The effects of a range of measures to reduce the tail pipe emissions and/or fuel consumption of modern passenger cars on petrol and diesel. TNO Report 2006.

[4] A. Cindie, S.P. Guillaume. Comparing effects of eco-driving training and simple advices on driving behavior., 15th meeting of the EURO Working Group on Transportation, Procedia - Social and Behavioral Sciences 2012 (54), 211 - 220.

[5] P. Bonnel, J. Kubelt, A. Provenza. Heavy-Duty Engines-Conformity Testing based on PEMS - Lessons Learned from the European Pilot Program. Publications Office of the European Union, 2011.

[6] GmbH, Vector Informatik. Manual VN1600 Interface Family. Stuttgart: s.n. 2013.

[7] R. Jančo, P. Élesztős. Thermal Field Simulation of Repair Threads in a Hole in the Cover of a Pressure Vessel by Welding Using Sysweld. In: Beran J, Bílek M, Žabka P (eds) Advances in Mechanism Design II. Mechanisms and Machine Science, Springer, Cham, 2017 (44), 191 - 198.

[8] R. Jančo, L. Écsi, P. Élesztős. FSW Numerical Simulation of Aluminium Plates by SYSWELD - Part II. Journal of Mechanical Engineering - Strojnicky časopis 2016 (66), No. 2, $29-36$. 
[9] Š. Gužela, F. Dzianik, M., Juriga, J. Kabát. Shell and Tube Heat Exchanger - the Heat Transfer Area Design Process. Journal of Mechanical Engineering - Strojnícky časopis 2017 (67), No. 2, 13 - 24.

[10] M. Bugár, V. Ferencey, J. Benedek. Electronic differential system design for small EV. In Transport means Kaunas: Kaunas University of Technology, 2015, 453 - 457. 